\title{
Hubungan Karakteristik Pasien dengan Tingkat Kepuasan Pelayanan pada Pasien Operasi Sub Bagian Fasial Plastik dan Bedah Rekonstruksi Bagian THT-KL RSUP Dr. M. Djamil Tahun 2019
}

\author{
Fauzan Junanda Putra ${ }^{1}$, Al Hafiz , Firdawati ${ }^{3}$ \\ ${ }^{1}$ Profesi Dokter Fakultas Kedokteran Universitas Andalas \\ ${ }^{2}$ Bagian THT-KL FK UNAND/ RSUP Dr. M. Djamil Padang \\ ${ }^{3}$ Bagian IImu Kesehatan Masyarakat FK UNAND
}

\section{A B S T R A C T}

Latar Belakang. Keberhasilan suatu rumah sakit dalam memberi pelayanan dapat dilihat dari kinerja dan kepuasan pasien. Kepuasan pasien adalah respon evaluatif, emosional atau afektif dari pasien terhadap pelayanan yang diberikan oleh penyedia layanan kesehatan serta harapan terhadap pelayanan tersebut. Kepuasan masing-masing pasien dapat berbeda tergantung harapan dan realita yang didapatkan. Hal tersebut dapat disebabkan beberapa faktor seperti umur, jenis kelamin, pekerjaan dan pendidikan. Penelitian ini dilakukan untuk mengetahui hubungan karakteristik pasien tersebut dengan tingkat kepuasan pelayanan pasien di divisi fasial plastik dan bedah rekonstruksi bagian THT RSUP Dr. M. Djamil Padang.

Metode. Jenis penelitian ini adalah penelitian analitik dengan desain cross sectional. Responden dalam penelitian ini berjumlah 37 orang. Pengambilan sampel dilakukan menggunakan metode purposive sampling. Instrumen yang digunakan adalah kuesioner kepuasan untuk mendapatkan data primer dan rekam medik untuk data sekunder.

Hasil. Penelitian menunjukkan bahwa subjek penelitian lebih banyak usia dewasa tua $(56,76 \%)$, berjenis kelamin perempuan (51,35\%), mempunyai pekerjaan (51,36\%), berpendidikan tinggi $(81,08 \%)$ dan status kepesertaan non BPI (56,8\%). Hasil analisis bivariat menunjukkan tidak adanya hubungan antara umur, jenis kelamin, pendidikan dan pekerjaan dengan tingkat kepuasan pasien. Didapatkan nilai $p$ masing-masing $p=0,366, p=0,692, p=0,554$ dan $p=0,845$. Sedangkan terdapat hubungan antara status kepesertaan dengan tingkat kepuasan dengan nilai $p=0,033$.

Kesimpulan. Tidak terdapat hubungan antara karakteristik pasien dengan tingkat kepuasan pelayanan pada pasien di divisi fasial plastik dan bedah rekonstruksi bagian THT RSUP Dr. M. Djamil Padang kecuali pada variabel status kepesertaan asuransi kesehatan.
Kata kunci: kepuasan, pendidikan, pekerjaan, status kepesertaan asuransi kesehatan.

Introduction. The success of a hospital in providing services can be seen from the performance of health care provider and patient satisfaction. Patient satisfaction is the evaluative, emotional or affective response of the patient to the service provided by the health care provider and the expectation of the service. The satisfaction of each patient can be different depending on the expectations and reality. This can be caused by several factors such as age, gender, occupation and education. This study was conducted to determine the relationship of these patient characteristics with the level of patient service satisfaction in the plastic facial and reconstructive surgery division of ENT department of Dr. M. Djamil hospital.

Method. The research is analytic research with cross sectional design. Respondents in this study were 37 people. Sampling was done using a purposive sampling method. This study used satisfaction questionnaires and medical record as an research instrument.

Result. The results showed that there were more subjects in the old adult age category (56.76\%), female (51.35\%), had a job (51.35\%), had a high education (81.08\%), and non PBI membership status (56,8\%). The results of bivariate analysis showed that there was no relationship between age, sex, education and occupation with the level of satisfaction. $P$ values obtained respectively $p=0.366, p=0.692, p=0.554$ and $p=0.845$. Whereas there are relationship between patient health assurance membership status with patient satisfaction by $p$ values 0,033 .

Conclusion. There is no relationship between patient characteristics with the level of service satisfaction except for health assurance membership status. 
Keywords: education, health assurance membership status, occupation, satisfaction.

\section{Apa yang sudah diketahui tentang topik ini?}

Karakteristik pasien seperti usia, jenis kelamin, pendidikan, pekerjaan, dan status kepesertaan asuransi kesehatan (BPJS) merupakan salah satu faktor yang dapat mempengaruhi tingkat kepuasan pasien.

\section{Pendahuluan}

Menurut WHO (World Health Organization), rumah sakit adalah bagian integral dari suatu organisasi sosial dan kesehatan yang menyediakan pelayanan paripurna (comprehensive), penyembuhan penyakit (curative), dan pencegahan penyakit (preventive) kepada masyarakat. ${ }^{1}$ Berdasarkan undang-undang No.44 tahun 2009, rumah sakit merupakan institusi pelayanan kesehatan yang menyelenggarakan pelayanan kesehatan perorangan secara paripurna yang menyediakan pelayanan rawat inap, rawat jalan serta gawat darurat. $^{2}$

Rumah sakit berperan penting dalam memberikan pelayanan publik yang berkualitas. Keberhasilan suatu rumah sakit dalam memberi pelayanan dapat dilihat dari kinerja dan kepuasan pasien. Suatu kualitas disebut baik apabila pelayanan yang diberikan terhadap pasien setara atau melebihi apa yang diharapkan oleh pasien. Sedangkan kualitas disebut tidak baik apabila pelayanan yang diberikan berada di bawah apa yang diharapkan pasien. ${ }^{3}$

Rumah Sakit Umum Pusat (RSUP) Dr. M. Djamil adalah rumah sakit kelas A pendidikan dengan status Badan Layanan Umum (BLU), merupakan rumah sakit rujukan untuk wilayah Sumatera bagian tengah, melayani masyarakat di wilayah Provinsi Sumatera Barat, Riau, Jambi, Bengkulu, serta wilayah sumatera bagian selatan. ${ }^{4}$ Sesuai dengan motto RSUP Dr. M. Djamil yaitu "Kepuasan Anda Adalah Kepedulian Kami" dan Rencana Strategis Bisnis (RSB), berkeinginan menjadi rumah sakit pendidikan terbaik, berkualitas bagi peserta didik sesuai standar

\section{Apa yang ditambahkan pada studi ini?}

Pada penelitian ini usia, jenis kelamin, pendidikan dan pekerjaan tidak berhubungan dengan tingkat kepuasan pasien, sedangkan status kepesertaan asuransi kesehatan (BPJS) berhubungan dengan tingkat kepuasan pasien.

\section{CORRESPONDING AUTHOR}

Phone: 0895329703056

E-mail: fauzannanda11@gmail.com

ARTICLE INFORMATION

Received: July $30^{\text {th }}, 2020$

Revised: April 18 ${ }^{\text {th }}, 2021$

Available online: May $27^{\text {th }}, 2021$

kompetensi dan perkembangan ilmu pengetahuan, teknologi \& informasi, tempat kerja yang nyaman dan menyenangkan bagi seluruh jajaran rumah sakit, terbentuknya kerjasama yang profesional, serta terwujudnya kepuasan pelanggan, maka rumah sakit harus dapat menciptakan kepuasan pasien, sebab jika tidak tercapai, pasien sebagai pengguna pelayanan kesehatan di rumah sakit akan berpindah dan menggunakan pelayanan rumah sakit lain, sehingga akan menyebabkan penurunan kepercayaan dan pemanfaatan rumah sakit daerah sebagai institusi milik pemerintah.3,4

Pelayanan yang diberikan dapat dinilai dari ketidakpuasan pasien di rumah sakit tersebut. Data dari Instalasi Humas RSUP Dr. M. Djamil pada tahun 2014 menunjukkan bahwa terdapat 106 pengaduan dari hampir semua unit di rumah sakit. Persentase tertinggi terdapat pada pelayanan obat sebanyak $28,3 \%$, komunikasi petugas $(23,5 \%)$, fasilitas $(20,7 \%)$, pelayanan dokter dan perawat $(8,5 \%)$, tempat parkir $(7,5 \%)$ dan pelayanan administrasi $(2,8 \%) .5,6$ Pada tahun 2017 terdapat sebanyak 109 kasus pengaduan terhadap berbagai aspek meliputi, 21 (19,2\%) pengaduan terhadap pelayanan dari dokter, 8 $(7,3 \%)$ pengaduan terhadap komunikasi dokter, $4(3,6 \%)$ pengaduan terhadap pelayanan perawat, $14(12,8 \%)$ terhadap pelayanan petugas, $5(4,5 \%)$ terhadap biaya, 2 (1,83\%) terhadap BPJS, 3 $(2,7 \%)$ terhadap lahan parkir dan $5 \quad(4,5 \%)$ terhadap fasilitas yang ada di rumah sakit. Sedangkan pada tahun 2018 terdapat sebanuak 63 pengaduan dan pada tahun 2019 sampai dengan bulan November sudah terdapat sebanyak 69 pengaduan. $^{7}$ 
Kepuasan pasien adalah respon evaluatif, emosional atau afektif dari pasien terhadap pelayanan yang diberikan oleh penyedia layanan kesehatan seperti rumah sakit serta harapan terhadap pelayanan tersebut. 8 Menurut Kotler, kepuasan adalah tingkat keadaan seseorang yang merupakan hasil perbandingan antara penampilan atau outcome atau pelayanan yang diterima dengan ekspektasi atau harapan seseorang. ${ }^{9}$

Dari survey kepuasan yang dilakukan di RSUP Dr. M. Djamil terhadap 404 responden pada tahun 2014, sebanyak 70,8\% menyatakan cukup puas terhadap pelayanan yang diberikan, 24\% puas dan 5,2\% menyatakan tidak puas. Hal ini bisa menggambarkan pelayanan yang diberikan belum optimal, karena dapat dilihat masih ada sekitar $5,2 \%$ yang menyatakan tidak puas dan hanya $24 \%$ yang puas akan pelayanan yang diberikan. ${ }^{10}$

Salah satu pelayanan spesialis yang terdapat di RSUP Dr. M. Djamil adalah spesialis bagian THT dengan sembilan subspesialis, termasuk di dalamnya adalah subspesialis bedah fasial plastik dan bedah rekonstruksi. ${ }^{11}$ Bedah plastik dan rekonstruksi adalah salah satu subspesialis THT-KL yang dapat menangani keadaan yang memerlukan tindakan bedah pada wajah, seperti pada keadaan trauma pada wajah ataupun devasi septum. Prosedur pembedahan dapat memberikan reaksi emosional seperti kecemasan yang akan mempengaruhi perubahan fisik dan psikologi pasien. Kecemasan ini dapat diakibatkan oleh kurangnya pengetahuan atau ketidaktahuan pasien terhadap prosedur pembedahan yang akan dijalani.

Tingkat kepuasan pemberian pelayanan pada pasien yang akan dioperasi dipengaruhi oleh beberapa faktor, salah satunya adalah pemberian informasi perioperatif. Menurut Heidegger dkk, pemberian informasi perioperatif yang jelas dan baik akan menimbulkan pemahaman pada pasien sehingga dapat mengurangi kesalahpahaman. Pemberian informasi yang jelas akan memudahkan pasien dalam mengambil keputusan yang pada akhirnya akan mempengaruhi kepuasan pasien itu sendiri. ${ }^{12-14}$

Menurut Sitzia dan Wood, karakteristik atau ciri-ciri seserang merupakan faktor penting yang dapat mempengaruhi tingkat kepuasan pasien, seperti umur, jenis kelamin, pendidikan, dan status sosioekonomi seseorang. ${ }^{15}$
Notoadmodjo mengemukakan bahwa karakteristik individu digolongkan menjadi tiga, yaitu; ciri-ciri demografi seperti umur dan jenis kelamin, struktur sosial seperti tingkat pendidikan dan pekerjaan, serta manfaat-manfaat kesehatan seperti keyakinan bahwa pelayanan kesehatan dapat membantu proses penyembuhan penyakit. ${ }^{16,17}$

Menurut penelitian yang dilakukan oleh Sari pada tahun 2017 tentang analisis tingkat kepuasan pasien terhadap pelayanan keperawatan di RSUD dr.Rasidin Padang, mendapatkan hasil bahwa karakteristik pasien berupa umur, jenis kelamin, dan pendidikan pasien di ruang rawat inap RSUD dr. Rasidin Padang tidak memiliki hubungan yang signifikan dengan tingkat kepuasan pasien. ${ }^{18}$ Begitupun dengan penelitian oleh Merkouris tahun 2004, yang menyatakan bahwa karakteristik pasien merupakan faktor yang dapat mempengaruhi dari tingkat kepuasan pasien. ${ }^{19}$ Survey awal yang peneliti lakukan terhadap 10 pasien di bagian THT RSUP Dr. M. Djamil, didapatkan hasil bahwa 6 menyatakan puas terhadap pelayanan yang diberikan, 4 menyatakan tidak puas dan tidak ada yang menyatakan sangat puas terhadap pelayanan yang diberikan.

Dari hasil penelitian dan masalah yang dijabarkan diatas, maka peneliti tertarik untuk meneliti tentang hubungan karakteristik pasin dengan kepuasan pasien operasi fasial plastik bedah rekonstruksi THT-KL RSUP Dr. M. Djamil Padang.

\section{Metode}

Jenis penelitian ini adalah penelitian observasional analitik kuantitatif dengan desain penelitian cross-sectional study. Penelitian dilaksanakan di bagian RSUP Dr. M Djamil Padang dengan periode waktu penelitian Januari sampai Maret 2020. Populasi penelitian ini adalah seluruh pasien operasi fasial plastik dan bedah rekonstruksi THT-KL RSUP Dr. M. Djamil pada bulan Januari 2018 sampai Desember 2019. Sampel penelitian dipilih secara purposive 
sampling dari semua populasi. Kriteria inklusi pada penelitian ini adalah: pasien yang telah melakukan operasi fasial plastik dan bedah rekonstruksi dan pasien yang bersedia menjadi responden dalam penelitian. Kriteria eksklusi pada penelitian ini adalah: pasien tidak menjawab setelah tiga kali ditelepon dan pasien yang setelah tiga kali kunjungan tidak berada di tempat.

Instrumen dalam penelitian ini menggunakan kuesioner yang telah divalidasi untuk mendapatkan data primer dengan wawancara melalui telepon dan data sekunder, yaitu data rekam medis pasien yang terdapat di bagian rekam medis RSUP Dr M. Djamil Padang.

Data dianalisis secara univariat dan bivariat menggunakan program komputer. Analisis univariat dilakukan untuk melihat distribusi frekuensi dari masing-masing variabel. Sedangkan analisis bivariat dianalisis dengan uji chi-square untuk melihat adanya hubungan antara variabel dependen dan independent. Penelitian ini telah lulus kaji etik dengan nomor surat: 95/KEPK/2020.

\section{Hasil}

Total sampel pada penelitian ini berjumlah 37 sampel yang telah memenuhi kriteria inklusi dan eksklusi penelitian.

\section{Karakteristik Responden}

Tabel 1. Distribusi Frekuensi Karakteritik Pasien Fasial Plastik dan Bedah Rekonstruksi

\begin{tabular}{|c|c|c|c|}
\hline Klasifikasi & & $\mathrm{N}$ & $\%$ \\
\hline \multicolumn{4}{|l|}{ Usia } \\
\hline & Dewasa & 16 & 43,24 \\
\hline & Muda & & \\
\hline & Dewasa & 21 & 56,76 \\
\hline & Tua & & \\
\hline \multicolumn{4}{|l|}{ Jenis Kelamin } \\
\hline & Laki-laki & 18 & 48,64 \\
\hline & Perempuan & 19 & 51,35 \\
\hline \multicolumn{4}{|l|}{ Pendidikan } \\
\hline & Rendah & 7 & 18,91 \\
\hline & Tinggi & 30 & 81,08 \\
\hline \multicolumn{4}{|l|}{ Pekerjaan } \\
\hline & Bekerja & 19 & 51,36 \\
\hline & Tidak Bekerja & 18 & 48,64 \\
\hline \multicolumn{4}{|l|}{ Status } \\
\hline \multirow[t]{2}{*}{ Kepesertaan } & PBI & 16 & 43,2 \\
\hline & Non PBI & 21 & 56,8 \\
\hline Jumlah & & 37 & 100 \\
\hline
\end{tabular}

Ket $: *$ PBI $=$ Penerima Bantuan Iuran, ${ }^{* *}$ Non PBI $=$ Bukan Penrima Bantuan Iuran

Tabel 1 menunjukkan distribusi frekuensi dari variabel yang diteliti. Berdasarkan usia, responden terbanyak pada usia dewasa tua $(56,76 \%)$, berjenis kelamin perempuan $(51,35 \%)$, berpendidikan tinggi (81,08\%), mempunyai pekerjaan $(51,36 \%)$ dan status kepesertaan BPJS non PBI (56,8\%).

\section{Tingkat Kepuasan}

Tabel 2. Distribusi Tingkat Kepuasan Setiap Aspek Kepuasan

\begin{tabular}{llcc}
\hline $\begin{array}{l}\text { Domain } \\
\text { Kepuasan }\end{array}$ & Tingkat & $\mathbf{f}$ & $\mathbf{\%}$ \\
\hline \multirow{4}{*}{ Reliability } & Sangat Puas & 6 & 16,2 \\
& Puas & 21 & 56,8 \\
& Tidak Puas & 10 & 27 \\
\hline \multirow{3}{*}{ Responsiveness } & Sangat Puas & 6 & 16,2 \\
& Puas & 21 & 56,8 \\
& Tidak Puas & 10 & 27 \\
\hline \multirow{3}{*}{ Essurance } & Sangat Puas & 5 & 13,5 \\
& Puas & 23 & 62,2 \\
& Tidak Puas & 9 & 24,3 \\
\hline Tangible & Sangat Puas & 6 & 16,2 \\
& Puas & 19 & 51,4 \\
& Tidak Puas & 12 & 32,4 \\
\hline & Sangat Puas & 7 & 18,9 \\
& Puas & 20 & 54,1 \\
& Tidak Puas & 10 & 27 \\
\hline
\end{tabular}

Tabel 2 menunjukkan tingkat kepuasan responden/ pasien pada setiap aspek kepuasan. Didapatkan bahwa responden/ pasien lebih banyak merasa puas pada aspek assurance. Sedangkan pasien/ responden lebih banyak merasakan tidak puas pada aspek emphaty.

Tabel 3. Distribusi Tingkat Kepuasan

\begin{tabular}{lcc}
\hline Kepuasan & f & $\mathbf{\%}$ \\
\hline Tidak Puas & 13 & 35,1 \\
Puas & 14 & 37,8 \\
Sangat Puas & 10 & 27,0 \\
\hline Total & 37 & 100 \\
\hline
\end{tabular}

Tabel 3 menunjukkan bahwa pasien yang merasakan puas sebanyak 37,8\%. 


\section{Hubungan Karakteristik Pasien Dengan Tingkat Kepuasan}

Tabel 4. Hubungan Karakteristik Pasien Dengan Tingkat Kepuasan

\begin{tabular}{lc}
\hline Karakteristik Pasien & Nilai p \\
\hline Usia & 0,366 \\
Jenis Kelamin & 0,692 \\
Pendidikan & 0,554 \\
Pekerjaan & 0,845 \\
Status Kepesertaan BPJS & 0,033 \\
\hline
\end{tabular}

Tabel 4 menunjukkan bahwa usia, jenis kelamin, pendidikan dan pekerjaan tidak memiliki hubungan dengan tingkat kepuasan pasien. Terdapat hubungan antara status kepesertaan dengan tingkat kepuasan dengan nilai p 0,033.

\section{Pembahasan}

\section{Analisis Univariat}

a. Karakteristik Pasien

Pada variabel umur didapatkan rata-rata responden berumur 32 tahun. Hasil yang didapat sejalan dengan penelitian yang dilakukan oleh Mustika (2014) dengan subjek penelitian terbanyak berada pada kelompok umur $>30$ tahun (81,5\%). ${ }^{20}$ Penelitian yang dilakukan oleh WHO terhadap 9 negara berkembang, populasi terbanyak dimasyarakat adalah yang berusia dibawah 5 tahun dan yang berusia 30-35 tahun. Dua kelompok ini merupakan kelompok umur terbanyak menggunakan fasilitas pelayanan kesehatan. Sedangkan menurut Trisnantoro (2006), menyatakan bahwa seiring bertambahnya usia maka juga akan terjadi peningkatan akan kebutuhan pelayanan kesehatan yang disebabkan oleh meningkatnya akan kebutuhan pengobatan dan pelayanan kuratif. ${ }^{21}$

Berdasarkan kelompok jenis kelamin, didapatkan bahwa responden perempuan lebih banyak jumlah nya, yaitu 19 orang dibandingkan dengan laki-laki sebanyak 18 orang. Hasil ini sejalan dengan penelitian Pratama (2013) yang mendapatkan bahwa subjek penelitian berjenis kelamin perempuan lebih banyak, yaitu 56 orang. ${ }^{22}$ Menurut Smet (1994) perempuan pada umumnya lebih banyak melaporkan gejala sakit dan berkonsultasi dengan dokter dibandingkan dengan laki-laki. ${ }^{23}$

Pada kelompok pekerjaan, didapatkan hasil bahwa lebih banyak responden yang bekerja dari pada tidak bekerja. Hasil ini sesuai dengan penelitian Kaporina (2013) yang juga mendapatkan bahwa lebih banyak subjek penelitian yang bekerja dari pada tidak bekerja. ${ }^{24}$ Menurut Notoadmodjo, penghasilan dari pekerjaan yang dijalani mempengaruhi seseorang dalam pemanfaatan pelayanan kesehatan maupun pencegahan. Seseorang yang berpenghasilan lebih rendah cenderung akan kurang dalam memanfaatkan layanan kesehatan yang ada, bisa dikarenakan kurang nya kemampuan untuk membayar tagihan obat ataupun transportasi. ${ }^{16,17}$

Sedangkan pada variabel pendidikan, didapatkan hasil pada kategori tingkat pendidikan rendah sebanyak 7 orang dan pendidikan tinggi sebanyak 37 orang. Hasil ini sejalan dengan penelitian Mustika (2014) yang juga mendapatkan bahwa lebih banyak pasien atau responden dengan tingkat pendidikan tinggi dibandingkan dengan pendidikan rendah. ${ }^{20}$ Pendidikan sangat erat kaitannya dengan kesadaran dan pengetahuan seseorang terhadap pelayanan kesehatan. Secara tidak langsung, pendidikan juga berpengaruh pada bagaimana sikap seseorang dalam memanfaatkan pelayanan kesehatan yang tersedia. Menurut Jacobalis (2000) pendidikan sangat mempengaruhi pola pikir rasional dan irrasional seseorang dalam hal mengambil keputusan, menggunakan dan memanfaatkan pelayanan kesehatan yang tersedia. ${ }^{25}$

Pada kelompok status kepesertaan, didapatkan hasil bahwa lebih banyak pasien dengan kepesertaan non PBI sebanyak 56,8\% dibanding dengan PBI sebanyak 43,2\%. Penelitian Mardiati (2018) juga mendapatkan hasil bahwa lebih banyak peserta non PBI dari pada PBI. ${ }^{26} \mathrm{Hal}$ ini bisa dikarenakan pada kelompok non PBI yang termasuk didalamnya PNS dan pensiunan yang langsung terdaftar sebagai peserta Jaminan Kesehatan Nasional (JKN), serta karyawan swasta yang jaminan kesehatannya dialihkan langsung oleh perusahaan terkait dari Jamsostek ke JKN. ${ }^{26}$

b. Kepuasan Pasien

Menurut Kotler, kepuasan adalah tingkat perasaan seseorang terhadap pelayanan yang diberikan atau kinerja yang dirasakan dibandingkan dengan harapan. ${ }^{9}$ Dari hasil yang didapatkan, sebanyak $35,1 \%$ masih merasa tidak puas akan pelayanan yang diterima, $37,8 \%$ puas dan $27 \%$ merasa sangat puas akan pelayanan. Kepuasan pasien dapat meningkatkan reputasi dari suatu rumah sakit. Pasien yang puas terhadap suatu pelayanan, biasanya akan menunjukkan 
perilaku suka secara gamblang yang dapat menguntungkan pihak penyedia layanan kesehatan. Hal ini dikarenakan pasien akan cenderung mengeskpresikan bahwa pasien tersebut puas akan layanan dengan cara yang positif seperti memuji dan lebih memilih rumah sakit tertentu dibanding yang lain, sehingga dapat menjaga atau meningkatkan reputasi dari rumah sakit tersebut. ${ }^{27}$

i. Kesesuaian Kepuasan Pasien

Hasil nilai yang diberikan pasien terhadap isian kuesioner tentang kenyataan dan harapan terhadap pelayanan yang diberikan terlihat pada tabel 5 .

Tabel 5 Nilai Harapan dan Kenyataan

\begin{tabular}{|c|c|c|c|c|c|c|c|}
\hline \multirow{3}{*}{$\mathrm{R}$} & \multirow{3}{*}{ I } & \multicolumn{4}{|c|}{ Nilai } & \multicolumn{2}{|c|}{ HP } \\
\hline & & \multicolumn{2}{|c|}{$\mathrm{Yi}$} & \multicolumn{2}{|c|}{$\mathrm{Xi}$} & \multirow[t]{2}{*}{ Yi } & \multirow[t]{2}{*}{$\mathrm{Xi}$} \\
\hline & & Max & Min & Max & Min & & \\
\hline 3 & 25 & 175 & 161 & 175 & 153 & 4266 & 4080 \\
\hline 7 & & & & & & & \\
\hline
\end{tabular}

Tabel diatas menunjukkan bahwa nilai yang diberikan terhadap harapan adalah 4266 dan kenyataan 4080. Sehingga terdapat perbedaan antara harapan dan kenyataan sebesar 186.

Tingkat Kesesuaian $(T K i)=\frac{X i(\text { Kenyataan })}{Y i(\text { Harapan })} \times 100 \%$ Tingkat Kesesuaian $(T K i)=\frac{4080}{4266} \times 100 \%$

Tingkat Kesesuaian $(T K i)=95,63 \%$

Gambar 1 Tingkat Kesesuaian Kepuasan Pasien

Keadaan diatas mengindikasian bahwa subbagian fasial plastik dan bedah rekonstruksi di bagian THT-KL RSUP Dr. M. Djamil telah mampu memenuhi 95,63\% harapan pasien terhadap pelayanan, dan perlu perbaikan dan peningkatan pada $4,37 \%$ lainnya.

ii. Penyebaran Faktor-Faktor yang Mempengaruhi Kepuasan Pasien

Pemetaan terhadap item-item yang ada pada kuesioner kepuasan pasien yang mempengaruhi kepuasan dilakukan dengan diagram kartesius. Penggunaan diagram kartesius dapat menggambarkan poin atau item mana yang harus diperbaiki ataupun yang harus dipertahankan pelayanannya.
Data yang sudah didapatkan dan diolah kemudian dikelompokkan menjadi empat kuadran pada diagram kartesius. Untuk menentukan letak diagram, dicari rata-rata dari rata-rata $\mathrm{X}$ (kenyataan/kinerja) dan Y (harapan). Kuadran dibagi menjadi empat bagian dipotong oleh garis yang dibentuk rata-rata $\mathrm{X}$ dan $\mathrm{Y}$.

Hasil penilaian secara rata-rata terhadap harapan dan kualitas pelayanan disajikan dalam bentuk grafik, yaitu Diagram Kartesius yang terdiri dari empat kuadran.

\section{A. Kuadran I (Prioritas Utama)}

Menunjukkan tingkat kepentingan terhadap atribut pelayanan tinggi akan tetapi dalam pelaksanaannya belum optimal. Akibatnya responden/ pasien belum puas sehingga atribut yang termasuk di kuadran ini wajib menjadi prioritas utama dalam perbaikan.

B. Kuadran II (Pertahankan Prestasi)

Menunjukkan tingkat harapan pasien akan pelayanan tinggi dan kualitas pelayanan yang diterima juga dirasakan tinggi. Hal ini menggambarkan bahwa atribut kualitas pelayanan yang ada pada kuadran ini telah berhasil dilakukan sehingga pasien merasakan kepuasan.

C. Kuadran III (Prioritas Rendah)

Pada kuadran ini menunjukkan bahwa harapan pasien akan pelayanan rendah dan kualitas pelayanan yang dirasakan pasien juga rendah. Sehingga atribut dalam kuadran ini dianggap kurang penting dan kualitas pelayanan yang dirasakan juga biasa-biasa saja, karena itu prioritas kuadran ini untuk perbaikan dikategorikan rendah

D. Kuadran IV (Berlebihan)

Menunjukkan tingkat harapan atas atribut kualitas pelayanan pada kuadran ini rendah atau dianggap kurang penting akan tetapi dalam pelaksanaannya pelayanan yang diberikan justru tinggi. Sehingga dikategorikan berlebihan walaupun pasien merasa puas akan pelayanan yang diberikan. 
Tabel 6. Penyebaran Data dalam Diagram Kartesius

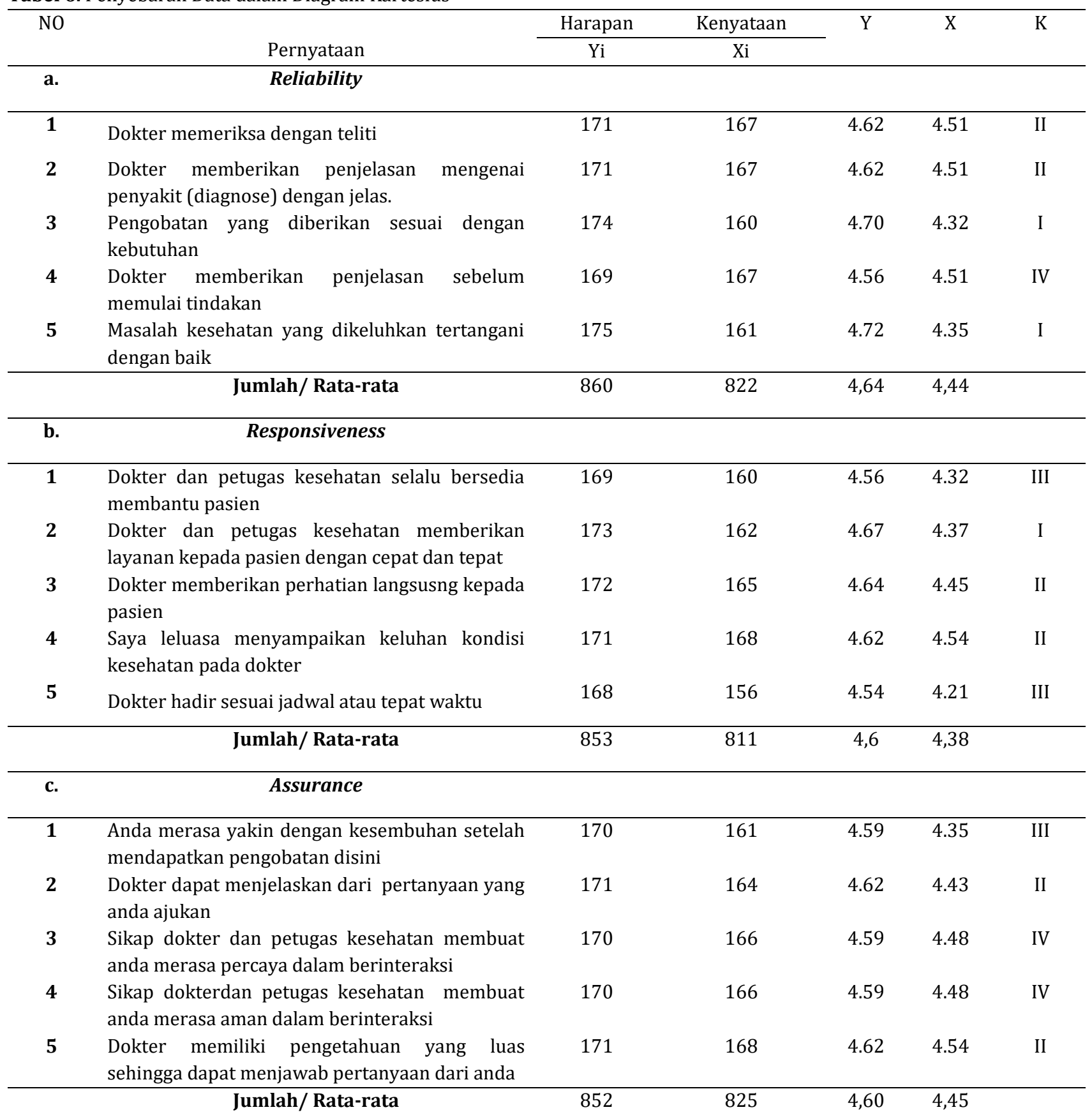

d.

Emphaty

\begin{tabular}{|c|c|c|c|c|c|c|}
\hline 1 & $\begin{array}{l}\text { Dokter dan petugas kesehatan memberikan } \\
\text { perhatian individual kepada pasien }\end{array}$ & 166 & 158 & 4.48 & 4.27 & III \\
\hline 2 & $\begin{array}{l}\text { Petugas kesehatan memberikan pelayanan } \\
\text { peniuh perhatian }\end{array}$ & 171 & 162 & 4.62 & 4.37 & I \\
\hline 3 & Dokter memahami kebutuhan pasien & 172 & 160 & 4.64 & 4.32 & I \\
\hline 4 & Dokter mengutamakan kebutuhan pasien & 170 & 162 & 4.59 & 4.37 & III \\
\hline \multirow[t]{2}{*}{5} & $\begin{array}{l}\text { Dokter dan petugas kesehatan selalu bersikap } \\
\text { sopan }\end{array}$ & 172 & 166 & 4.64 & 4.48 & II \\
\hline & Jumlah/ Rata-rata & 851 & 808 & 4,6 & 4,36 & \\
\hline
\end{tabular}




\begin{tabular}{|c|c|c|c|c|c|c|}
\hline \multirow[t]{2}{*}{ NO } & \multirow[b]{2}{*}{ Pernyataan } & Harapan & Kenyataan & \multirow[t]{2}{*}{ Y } & \multirow[t]{2}{*}{$\mathrm{X}$} & \multirow[t]{2}{*}{$\mathrm{K}$} \\
\hline & & Yi & $\mathrm{Xi}$ & & & \\
\hline e. & Tangible & & & & & \\
\hline 1 & Ruang tunggu bersih dan nyaman & 170 & 163 & 4.59 & 4.40 & III \\
\hline 2 & Kursi di ruang tunggu membuat saya nyaman & 166 & 153 & 4.48 & 4.13 & III \\
\hline 3 & Ruangan dokter bersih dan nyaman & 174 & 167 & 4.70 & 4.51 & II \\
\hline 4 & $\begin{array}{l}\text { Penampilan dari dokter rapi sesuai dengan } \\
\text { lingkungan kerja }\end{array}$ & 174 & 175 & 4.70 & 4.72 & II \\
\hline 5 & Petunjuk arah memadai & 166 & 156 & 4.48 & 4.21 & III \\
\hline & Jumlah/ Rata-rata & 850 & 814 & 4,59 & 4,4 & \\
\hline & Total & 4266 & 4080 & & & \\
\hline & Rata-Rata & 115,29 & 110,27 & 4,61 & 4,41 & \\
\hline
\end{tabular}

\section{Diagram Kartesius}

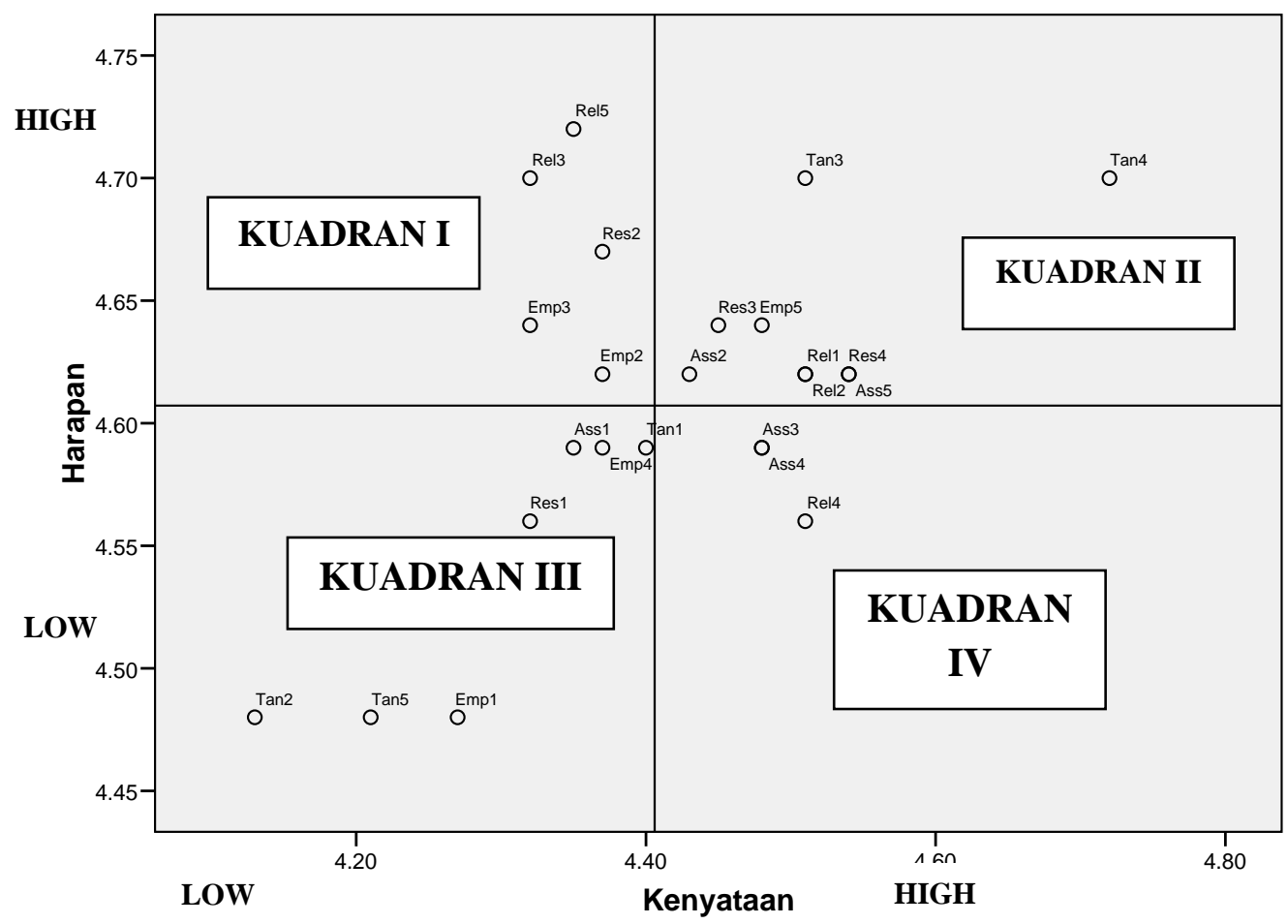

Gambar 2 Diagram Kartesius 
Tabel 7 Ringkasan Posisi Indikator Pelayanan Dalam Diagram Kartesius

\begin{tabular}{|c|c|}
\hline Kuadran & Indikator Pelayanan \\
\hline Kuadran I & $\begin{array}{l}\text { Pengobatan yang diberikan sesuai dengan } \\
\text { kebutuhan } \\
\text { Masalah kesehatan yang dikeluhkan } \\
\text { tertangani dengan baik } \\
\text { Dokter dan petugas kesehatan } \\
\text { memberikan layanan kepada pasien } \\
\text { dengan cepat dan tepat } \\
\text { Petugas kesehatan memberikan pelayanan } \\
\text { peniuh perhatian } \\
\text { Dokter memahami kebutuhan pasien }\end{array}$ \\
\hline $\begin{array}{c}\text { Kuadran } \\
\text { II }\end{array}$ & $\begin{array}{l}\text { Dokter memeriksa dengan teliti } \\
\text { Dokter memberikan penjelasan mengenai } \\
\text { penyakit (diagnose) dengan jelas. } \\
\text { Dokter memberikan perhatian langsusng } \\
\text { kepada pasien } \\
\text { Saya leluasa menyampaikan keluhan } \\
\text { kondisi kesehatan pada dokter } \\
\text { Dokter dapat menjelaskan dari } \\
\text { pertanyaan yang anda ajukan } \\
\text { Dokter memiliki pengetahuan yang luas } \\
\text { sehingga dapat menjawab pertanyaan dari } \\
\text { anda } \\
\text { Dokter dan petugas kesehatan selalu } \\
\text { bersikap sopan } \\
\text { Ruangan dokter bersih dan nyaman } \\
\text { Penampilan dari dokter rapi sesuai } \\
\text { dengan lingkungan kerja }\end{array}$ \\
\hline $\begin{array}{c}\text { Kuadran } \\
\text { III }\end{array}$ & $\begin{array}{l}\text { Dokter dan petugas kesehatan selalu } \\
\text { bersedia membantu pasien } \\
\text { Dokter hadir sesuai jadwal atau tepat } \\
\text { waktu } \\
\text { Anda merasa yakin dengan kesembuhan } \\
\text { setelah mendapatkan pengobatan disini } \\
\text { Dokter dan petugas kesehatan } \\
\text { memberikan perhatian individual kepada } \\
\text { pasien } \\
\text { Dokter mengutamakan kebutuhan pasien } \\
\text { Ruang tunggu bersih dan nyaman } \\
\text { Kursi di ruang tunggu membuat saya } \\
\text { nyaman } \\
\text { Petunjuk arah memadai }\end{array}$ \\
\hline $\begin{array}{c}\text { Kuadran } \\
\text { IV }\end{array}$ & $\begin{array}{l}\text { Dokter memberikan penjelasan sebelum } \\
\text { memulai tindakan } \\
\text { Sikap dokter dan petugas kesehatan } \\
\text { membuat anda merasa percaya dalam } \\
\text { berinteraksi } \\
\text { Sikap dokter dan petugas kesehatan } \\
\text { membuat anda merasa aman dalam } \\
\text { berinteraksi }\end{array}$ \\
\hline
\end{tabular}

\section{Analisis Bivariat}

a. Hubungan Usia Dengan Tingkat Kepuasan Pelayanan

Hasil analisis menggunakan uji chi square didapatkan nilai $\mathrm{p}>0,05$ yang berarti tidak ada hubungan bermakna antara usia dengan tiingkat kepuasan. Hasil ini sejalan dengan penelitian yang dilakukan oleh Aulia di RS Islam Sultan Agung Semarang yang menunjukkan bahwa tidak terdapat hubungan antara usia dengan tingkat kepuasan pasien. ${ }^{28}$ Penelitian yang dilakukan oleh Anjaryani (2009) di RSUD Tugurejo Semarang, didapatkan hasil bahwa tidak adanya hubungan antara karakteristik umur dengan tingkat kepuasan pasien. ${ }^{29}$

Pada penelitian yang dilakukan Aulia (2014), tidak adanya hubungan antara usia dengan tingkat kepuasan pasien disebabkan karena setiap manusia, muda ataupun tua ingin mendapatkan kasih sayang, perhatian, dan setiap keluhannya didengarkan oleh tenaga kesehatan, baik itu dokter maupun perawat. ${ }^{28}$ Ini diperkuat oleh teori Maslow tentang motivasi dengan pendekatan hierarki kebutuhan manusia yang menyebutkan bahwa setiap manusia ingin merasakan memiliki dan dimiliki, cinta dan kasih sayang, serta harga diri sehingga antara yang muda dan tua sama-sama ingin mempunyai hubungan interpersonal yang baik. ${ }^{30}$

b.Hubungan Jenis Kelamin Dengan Tingkat Kepuasan Pelayanan

Pada variabel ini dilakukan uji chi-square dan didapatkan hasil berupa nilai p sebesar 0,692. Dimana nilai p yang didapat lebih besar dari 0,05 , menunjukkan bahwa tidak ada hubungan antara jenis kelamin dengan tingkat kepuasan dari pasien. Penelitian Anjaryani (2009) dan Aulia (2014) juga mendapatkan hasil yang sama, yaitu tidak adanya hubungan bermakna jenis kelamin dengan tingkat kepuasan pada pasien. ${ }^{28,29}$

Berdasarkan penelitian yang dilakukan Findik (2010), jenis kelamin mempengaruhi persepsi kepuasan seseorang. Dimana pada pasien laki-laki ditemukan lebih mudah puas dibandingkan pada pasien perempuan. Pasien perempuan akan lebih sering melaporkan masalah yang ada pada layanan kesehatan dibanding laki-laki. Perempuan akan menganggap kesehatannya lebih penting dan akan cenderung 
mengevaluasi terhadap layanan kesehatan yang diterima, tidak hanya untuk dirinya, juga untuk anggota keluarganya. ${ }^{31,32}$

c. Hubungan Pendidikan Dengan Tingkat Kepuasan Pelayanan

Didapatkan nilai $\mathrm{p}=0,554$, dimana nilai $\mathrm{p}$ $>0,05$ berarti tidak ada hubungan bermakna antara pendidikan dengan tingkat kepuasan pasien. Hasil ini sebanding dengan penelitian yang dilakukan oleh Aulia (2014), dimana lebih banyak responden yang berpendidikan tinggi dan tidak ada hubungan antara pendidikan dengan tingkat kepuasan pasien. ${ }^{28}$

Penelitian yang dilakukan oleh Ho (1998), menyebutkan bahwa seseorang yang berpendidikan tinggi lebih sadar dengan masalah kesehatannya, juga dengan hak nya sebagai pasien. Mereka akan cenderung lebih aktif untuk bertanya akan masalah kesehatannya dan meminta saran. Sehingga cenderung akan merasakan tidak puas dikarenakan harapan yang tinggi dibanding kenyataan yang diterima saat menerima pelayanan kesehatan. Berbeda dengan yang berpendidikan rendah, cenderung mempunyai harapan yang lebih rendah. ${ }^{33}$ Menurut Johansson (2002), seseorang dengan pendidikan yang tinggi punya tuntutan lebih akan pelayanan, yang secara tidak langsung mengarah kepada ekspektasi terhadap informasi lebih yang akan diberikan dan pendidikan tinggi dari tenaga kesehatan yang memberikan pelayanan. ${ }^{32}$

d.Hubungan Pekerjaan Dengan Tingkat Kepuasan Pelayanan

Pada penelitian ini didapatkan hasil bahwa tidak terdapat hubungan antara pekerjaan dengan tingkat kepuasan pasien. Hasil yang didapatkan sebanding dengan penelitian yang dilakukan oleh Triwardani (2017) yang juga menyatakan bahwa tidak ada hubungan antara pekerjaan dengan tingkat kepuasan pelayanan yang diterima. ${ }^{34}$

Menurut Ma'arat perasaan puas pada setiap individu tidaklah sama, akan tetapi, perasaan puas tersebut dapat terjadi hampir sama pada setiap individu dikarenakan terdapat pengaruh dari lingkungan dan masyarakat golongan tertentu, sehingga dapat dikatakan bahwa tidak hanya pekerjaan yang dapat mempengaruhi kepuasan seseorang.. ${ }^{35}$

e. Hubungan Status Kepesertaan Dengan Tingkat Kepuasan Pelayanan

https://doi.org/10.25077/jikesi.v1i3.83
Penelitian ini menunjukkan bahwa terdapat hubungan antara status kepesertaan dengan tingkat kepuasan pasien. Hasil ini sebanding dengan penelitian Mardiati (2018) yang menyatakan terdapat hubungan antara status kepesertaan dengan tingkat kepuasan pasien. ${ }^{26}$ Sedangkan penelitian yang dilakukan Triwardani (2017), tidak terdapat hubungan antara status kepesertaan dengan tingkat kepuasan pasien. ${ }^{34}$

Mardiati (2018) menyatakan dibanding pasien yang mendapatkan pelayanan kesehatan secara cuma-cuma ataupun membayar lebih murah, pasien yang membayar secara penuh akan menuntut lebih banyak, ingin mendapatkan pelayanan yang berkualitas serta cenderung tidak mudah puas. ${ }^{26}$

\section{Simpulan}

Pada penelitian ini, didapatkan responden lebih banyak pada kelompok usia dewasa tua dengan rata-rata usia 32 tahun, lebih banyak yang berjenis kelamin perempuan, bekerja, pendidikan tinggi dan status kepesertaan BPJS adalah non PBI.

Berdasarkan hasil penelitian, didapatkan hasil bahwa lebih banyak responden/ pasien yang merasakan puas dan sangat puas terhadap pelayanan yang diberikan dari pada responden/ pasien yang merasakan tidak puas.

Analisis menggunakan diagram kartesius, mendapatkan hasil bahwa terdapat beberapa atribut pelayanan yang tergolong ke dalam kuadran I, yaitu atribut-atribut yang menjadi prioritas utama dalam perbaikan pelayanan. Memberikan layanan dengan cepat, tepat dan penuh perhatian merupakan salah satu atribut pelayanan yang diprioritaskan untuk diperbaiki.

Penelitian ini juga mendapatkan bahwa tidak terdapat hubungan antara usia, jenis kelamin, pendidikan dan pekerjaan dengan tingkat kepuasan pasien. Terdapat hubungan status kepesertaan asuransi kesehatan dengan tingkat kepuasan pasien.

\section{Ucapan Terima Kasih}

Ucapan terimakasih diberikan kepada pihak RSUP Dr. M. Djamil Padang yang memberikan izin untuk melakukan penelitian di Sub Bagian Fasial Plastik dan Bedah Rekonstruksi 
Bagian THT-KL RSUP Dr. M. Djamil Padang, serta responden yang bersedia mengikuti penelitian ini.

\section{Daftar Pustaka}

1. WHO. Definisi rumah sakit. World Health Organization. www.who.int- Diakses 10 Oktober 2019.

2. Undang-Undang Nomor 44 Tahun 2009 tentang rumah sakit. Jakarta: Sekretariat Kabinet Republik Indonesia. 2009.

3. Anwar AP.Analisis kepuasan pasien rawat inap bangsal jantung di RSUD Raden Mattaher Jambi.2012;1(1):12.

4. Faluzi A.Analisis penerapan upaya pencapaian standar sasaran keselamatan pasien bagi profesi pemberi asuhan dalam peningkatan mutu pelayanan di Rawat Inap Rsup Dr.M.Djamil Padang tahun 2017.Jurnal Kesehatan Andalas.2018;7(4):35.

5. Sari L.Hubungan kepuasan pasien, citra Rumah sakit dan kepercayaan pasien dengan loyalitas pasien di Instalasi Rawat Jalan Rsup Dr. M Djamil Padang.(Master Tesis).Universitas Andalas;2017.

6. RSUP Dr. M. Djamil Padang. 2015. Laporan tahunan RSUP Dr. M. Djamil Padang Tahun 2014.

7. RSUP Dr. M. Djamil Padang. Laporan tahunan Instalasi HUMAS RSUP Dr. M. Djamil Padang.2019.

8. Ahdazumar U.Tingkat kepuasan pasien post operatif terhadap pelayanan perawat di ruangan recovery room.2013 Feb 4.

9. Kotler P, Keller KL. Marketing management.15th ed.London: Pearson Education, 2016. p.148-76.

10. Puska FKM UI. Laporan penelitian pengaruh akreditasi terhadap pelayanan rumah sakit tahun 2012 s/d 2014 di RSUP Dr. M. Djamil Padang.2014.

11. A D Rogers. The scope of plastic surgery. South African Journal of Surgery: 2013; 51(3): p.106-9.

12. Akbar F.Hubungan tingkat pengetahuan dengan kepuasan pemberian informed consent pasien pre operasi (undergraduate thesis).Universitas Muhamadiyah Semarang;2018.

13. Muttaqin, A. \& Sari, K. Asuhan keperawatan perioperatif: konsep, proses dan aplikasi. Jakarta: Salemba Medika.2009.p 56-8.

14. A, Zambouri.Preoperative evaluation and preparation for anesthesia and surgery.Hippokratia Quarterly Medical Journal. 2007; 11(1): 13.

15. Sitzia J, Wood N. Patient satisfaction: a review of issues and concepts. Soc. Sci. Med. 1997; 45: 1829 1843.

16. Notoatmodjo, S . Promosi kesehatan dan ilmu perilaku.Rhinea Cipta:Jakarta.2007; P. 43-64.

17. Notoatmodjo S. Promosi kesehatan dan ilmu perilaku. Jakarta: Rineka Cipta. 2010; P. 43-64.

18. Sari RY. Analisis tingkat kepuasan pasien terhadap pelayanan keperawatan dan faktor-faktor determinannya di ruang rawat inap RSUD dr. Rasidin Padang tahun 2017. Undergraduate Thesis.2017.

19. Merkouris A, Papathanassoglou EDE, Lemonidou C. Evaluation of patient satisfaction with nursing care: quantitative or qualitative approach? Int. J. Nurs. Stud. 2004; 41: 355-367.

20. Mustika R.Hubungan mutu pelayanan kesehatan dengan kepuasan pasien di Poliklinik THT Rumkital Dr. Ramelan Surabaya. Stikes Hang Tuah.Skripsi.2014.

21. Trisnantoro L. Memahami penggunaan ilmu ekonomi dalam manajemen rumah sakit. 2006: Gadjah Mada
University Press. 122-2.

22. Pratama FI.Hubungan karakteristik pasien dan kepuasan terhadap kualitas pelayanan kesehatan RSUD Palembang.Universitas Muhammadiyah Palembang.Skripsi.2013.

23. Smet B. kesehatan.Grasindo:Jakarta.1994.p.230.

24. Kaporina A.Gambaran tingkat kepuasan pasien terhadap pelayanan di Instalasi Rawat Inap Ruang B2 THT dan Kulit Kelamin RSUP Dr. Kariadi Semarang.Universitas Semarang.Skripsi.2013.

25. Jacobalis.Kumpulan tulisan terpilih tentang rumah sakit di Indonesia dalam dinamika sejarah, transformasi, globalisasi dan krisis nasional. Jakarta: Yayasan penerbit IDI.2000.

26. Mardiati N. Hubungan jenis fasilitas kesehatan dan status kepesertaan dengan kepuasan pasien peserta JKN terhadap pelayanan kefarmasian: Studi di fasilitas kesehatan tingkat pertama Kota Banjarbaru. Journal Of Current Pharmaeutical Sciences: 2018; 1(2): $p$.

27. Zeithaml, V.A. and Bitner, M.J. Services marketing: integrating customer focus across the firm, McGrawHill, New York, NY.2000.p176-181.

28. Aulia N.Analisis hubungan karakteristik pasien dengan kepuasan pelayanan Rawat Jalan Semarang Eye Center (SEC) RS Islam Sultan Agung Semarang.Jurnal Kesehatan Masyarakat.2(1).2014.

29. Anjaryani WD.Kepuasan pasien rawat inap terhadap pelayanan perawat di RSUD Tugurejo Semarang.Universitas Diponegoro.Tesis.2009.

30. Maslow AH. Motivasi dan kepribadian (teori motivasi dengan pendekatan hierarki kebutuhan manusia).PT.PBP: Jakarta.1994.

31. Findik YU. Patient satisfaction with nursing care and its relationship with patient characteristics.Nursing and Health Science.Trakya University.12.2010.p1629.

32. Johansson P, Oleni M, Fridlund B. Patient satisfaction with nursing care in the context of health care: a literature study. Scand. J. Caring Sci. 2002; 16: 337344.

33. Ho, F.N., O'Donnell, K.A. and Chen, Y.J., "Switching HMO providers", Marketing Health Services, Vol. 18 No. 1, 1998. pp. 23-7.

34. Triwardani Y.Faktor-faktor yang berhubungan dengan kepuasan pasien BPJS pada pelayanan di Puskesmas Pamulang.Universitas Islam Negeri Syarif Hidayatullah Jakarta.Skripsi.2017.

35. As'at, Mar'at. Psikologi industri, Penerbit Liberti, Yogyakarta, 1995. 